Jurnal Teknik Komputer AMIK BSI

Volume VI No.1 Januari 2020

P-ISSN 2442-2436, E-ISSN: 2550-0120

Akreditasi Ristekdikti, No: 21/E/KPT/2018

DOI: $10.31294 / j$ tk.v4i2

\title{
Pembangunan Sistem Informasi Penjualan Peralatan Kesehatan (Studi Kasus: PT. Kalikandri Banyu Bening)
}

\author{
Dewi Laraswati ${ }^{1}$, Fattya Ariani ${ }^{2}$ \\ ${ }^{1}$ Universitas Bina Sarana Informatika/Teknologi Komputer \\ e-mail: dewi.dwl@bsi.ac.id \\ ${ }^{2}$ STMIK Nusa Mandiri/Sistem Informasi \\ e-mail: fattya.fty@nusamandiri.ac.id

\begin{tabular}{ccc}
\hline Diterima & Direvisi & Disetujui \\
$13-10-2019$ & $17-12-2019$ & $30-01-2020$ \\
\hline
\end{tabular}

\begin{abstract}
Abstrak - Perkembangan teknologi informasi, secara otomatis menuntut semua bidang kegiatan untuk terkomputerisasi. PT. Kaliandri Banyu Bening menggunakan sistem penjualan konvensional atau manual, untuk analisa permasalahan digunakan diagram ishikawa, dan pada sistem yang berjalan memiliki banyak kelemahan yang menyebabkan data hilang,data dapat dimanipulasi,pengolahan data tidak efektif dan efisien, informasi tidak akurat, kesulitan pencarian data,pembuatan laporan memakan waktu lama sehingga menghambat dalam mengambil keputusan. Sistem yang terkomputerisasi adalah solusi yang tepat untuk masalah ini. Dengan desain sistem informasi penjualan alat kesehatan dengan metode waterfall, pencatatan, pengarsipan dan pencarian informasi penjualan dapat dilakukan secara efektif dan efisien. Sehingga dalam pengambilan keputusan dapat dilakukan dengan cepat dan akurat. komputerisasi juga sangat berguna untuk menjaga keamanan dokumendokumen penting perusahaan karena menggunakan kata sandi yang hanya diketahui oleh orang-orang yang terkait dengan sistem penjualan itu sendiri.
\end{abstract}

Kata Kunci: SI, Penjualan Peralatan Kesehatan, Diagram Fishbone

\begin{abstract}
The development of information technology, automatically demands all fields of activity to be computerized. PT. Kaliandri Banyu Bening uses a conventional or manual sales system, to analyze the problem is used Ishikawa diagram, and the system that runs has many weaknesses that cause data loss, data can be manipulated, data processing ineffective and inefficient, inaccurate information, difficulty finding data, making the report takes a long time so that it hampers decision making. A computerized system is the right solution for this problem. With the design of a medical device sales information system using the waterfall method, recording, archiving and searching for sales information can be done effectively and efficiently. So that in making decisions can be done quickly and accurately. computerization is also very useful for maintaining the security of important company documents because it uses passwords that are only known by people associated with the sales system itself.
\end{abstract}

Keywords: SI, Health Equipment Sales, Diagram Fishbone

\section{PENDAHULUAN}

Penerapan Information and Communication Technologies (ICT) telah banyak digunakan oleh para usahawan. Kebutuhan efisiensi waktu dan biaya menyebabkan setiap pelaku usaha merasa perlu menerapkan ICT dalam lingkungan kerja. Penerapan ICT menyebabkan perubahan pada kebiasaan kerja. Salah satu contoh penggunaan ICT adalah penerapan Enterprice Resource Planning (ERP).

Teknologi Informasi dan Komunikasi (TIK ) merupakan bentuk teknologi yang digunakan untuk menciptakan, menyimpan, mengubah, dan menggunakan informasi dalam segala bentuknya. Melalui pemanfaatan teknologi informasi ini, perusahaan mikro, kecil maupun menengah dapat memasuki pasar global. Banyak perusahaan yang awalnya kecil menggunakan Teknologi Informasi dan Komunikasi (TIK ) saat ini menjadi perusahaan raksasa hanya dalam waktu singkat karena memanfaatkan teknologi informasi dalam mengembangkan usahanya (Basry \& Sari, 2018).

PT. Kalikandri Banyu Bening adalah perusahaan yang bergerak di bidang penjualan peralatan kesehatan untuk di salurkan di Rumah Sakit seluruh indonesia, yang berdiri pada tanggal 7 Mei 2014. Pada system berjalaan yang ada selama ini data dan 
informasi yang diterima dan dikelola oleh PT. Kaliandri Banyu Bening setiap hari terus meningkat, sehingga dalam pengelolaannya sangat sulit jika masih dilakukan dengan cara manual. Mulai dari pencatatan customer yang membeli barang, pada saat proses transaksi penjualan dimana kecepatan dan keakutaran data harus diperhatikan, belum lagi penyimpanan data-data lainnya yang berhubungan dengan proses penjulan hingga sampai dengan pembuatan laporan. Sistem penjualan yang masih manual sering mengalami kendala seperti kesalahan dalam pencatatan (Christian \& Ariani, 2018), pembuatan laporan yang kurang afektif dan efisien serta akurat(Susanto \& Irawan, 2018).

Berdasarkan penelitian tersebut jelas untuk saat ini PT. Kalikandri Banyu Bening mempunyai permasalahan seluruh transaksi penjualan yang ada dicatat ke dalam buku dan diinput di Ms. Office Excel, tidak adanya backup data dan validasi data, bukti transaksi dengan membuat kwitansi sendiri, dan pemanfaatan komputer dalam pengolahan data belum maksimal. Oleh karena itu butuh perancangan sistem yang sudah terkomputerisasi.

Proses pengolahan data menggunakan sistem yang sudah terkomputerisasi membantu proses penjualan lebih cepat. Penyediaan laporan penjualan tepat waktu dan meminimalisir kesalahan data. (Yuni \& Muryani, 2018)

Berdasarkan uraian diatas peneliti merancang bangun sistem informasi penjualan peralatan kesehatan berbasis dekstop, untuk mengatasi permasalahan yang ada pada sistem penjualan agar pembuatan laporan lebih cepat dan informasinya lebih akurat.

\section{METODOLOGI PENELITIAN}

Metode yang digunakan untuk penelitian terdiri dari dua metode, yaitu metode pengumpulan data dan metode pengembangan sistem.

\section{Metode Pengumpulan data}

Untuk pengumpulan data menggunakan tiga cara yaitu :

a. Observasi

Penulis melakukan riset langsung terhadap penjualan peralatan kesehatan PT. Kalikandri Banyu Bening, untuk mengetahui permasalahan yang terjadi dan mengidentifikasi pemecahan masalah.

b. Wawancara

Metode wawancara adalah pendekatan yang berhubungan langsung dengan sumber data sehingga terjadi proses komunikasi dengan sistem tanya jawab.

dalam penelitian ini penulis mengadakan wawancara langsung dengan ibu Rahma yang berhubungan langsung dengan sistem penjualan untuk mendapatkan informasi yang di butuhkan.

c. Studi Pustaka
Pengumpulan data teoritis untuk mendapatkan teori-teori yang dibutuhkan dengan cara melihat Literature atau Referensi dari berbagai sumber.

\section{Metode Pengembangan Sistem}

Untuk metode pengembangan sistem yang digunakan adalah metode waterfall. Waterfall terdiri dari serangkaian tugas yang erat, mengikuti langkahlangkah pendekatan sistem.

a. Analisa (Analysis)

Merupakan proses pengumpulan kebutuhan sistem informasi. Untuk memahami dasar dari program yang akan dibuat, seorang analisis harus mengetahui ruang lingkup informasi, fungsi-fungsi yang dibutuhkan, kemampuan kinerja yang ingin dihasilkan dan perancangan antarmuka pemakai sistem informasi tersebut.

b. Perancangan (Design)

Perancangan sistem informasi merupakan proses bertahap yang memfokuskan pada empat bagian penting, yaitu: Struktur data, arsitektur sistem informasi, detil prosedur, dan karakteristik antar muka pemakai.

c. Pengkodean (Coding)

Pengkodean sistem informasi merupakan proses penulisan bahasa program agar sistem informasi tersebut dapat dijalankan oleh mesin.

d. Pengujian (Testing)

Proses ini akan menguji kode program yang telah dibuat dengan memfokuskan pada bagian dalam sistem informasi. Tujuannya untuk memastikan bahwa semua pernyataan telah diuji dan memastikan juga bahwa input yang digunakan akan menghasilkan output yang sesuai. Pada tahap ini pengujian ini dibagi menjadi dua bagian, pengujian internal dan pengujian eksternal. Pengujian internal bertujuan menggambarkan bahwa semua statement sudah dilakukan pengujian, sedangkan pengujian eksternal bertujuan untuk menemukan kesalahan serta memastikan output yang dihasilkan sesuai dengan yang diharapkan.

e. Pemeliharaan (Maintenance)

Proses ini dilakukan setelah sistem informasi telah digunakan oleh pemakai atau konsumen. Perubahan akan dilakukan jika terdapat kesalahan, oleh karena itu sistem informasi harus disesuaikan lagi untuk menampung perubahan kebutuhan yang diinginkan konsumen

\section{HASIL DAN PEMBAHASAN}

Pada tahap ini urutan yang dilakukan sesuai dengan metode yang digunakan metode waterfall.

\section{Perancangan Sistem}

Perancangan sistem di buat dengan melihat permasalahan yang ada pada PT. Kalikandri Banyu Bening. Penentukan permasalahan yang digunakan diagram Fishbone. Diagram Fishbone dapat 
mengidentifikasi dan mengorganisasi penyebabpenyebab yang mungkin timbul dari suatu efek spesifik dan kemudian memisahkan akar penyebabnya.(Laraswati \& Marlina, 2019)


Sumber : (Laraswati \& Ariani, 2019)

Gambar 1. Diagram Fishbone Identifikasi Masalah Pada PT. Kalikandri Banyu Bening

Tabel 1. Deskripsi Fishbone

\begin{tabular}{|c|c|c|c|}
\hline Kategori & Sebab & Masalah & Akibat \\
\hline Metode & $\begin{array}{ll}\text { - } & \text { Pencatatan transaksi } \\
\text { masih manual } \\
\text { - } & \text { Proses penjualan } \\
\text { masih konvensional } \\
\text { - } & \text { Prosedur sistem tidak } \\
& \text { diperbaharui }\end{array}$ & $\begin{array}{ll}\text { - } & \text { Seluruh Transaksi penjualan } \\
\text { yang ada dicatat ke dalam buku } \\
\text { dan diinput di Ms. Office Excel } \\
\text { tidak adanya backup data dan } \\
\text { validasi data } \\
\text { - } \quad \text { Bukti transaksi dengan membuat } \\
\text { kwitansi sendiri } \\
\text { - } \quad \text { Pemanfaatan komputer dalam } \\
\text { pengolahan data belum maksimal }\end{array}$ & $\begin{array}{ll}\text { - } & \text { Data mudah hilang dan } \\
\text { rusak. Memungkinkan } \\
\text { terjadinya kesalahan } \\
\text { dalam pencatatan data } \\
\text { - } \quad \text { Memungkinkan } \\
\text { kemudahan dalam } \\
\text { manipulasi data } \\
\text { - } \quad \text { Pengolahan data tidak } \\
\text { efektif dan efisien } \\
\end{array}$ \\
\hline Manusia & $\begin{array}{ll}\text { - } & \text { Kemampuan admin } \\
\text { dalam mengolah data }\end{array}$ & $\begin{array}{ll}\text { - } & \text { Banyaknya transaksi setiap } \\
\text { harinya memungkinkan } \\
\text { ketidaktelitian dalam mencatat } \\
\text { dan menginput data } \\
\text { - } \quad \text { Tidak memahami SOP yang ada }\end{array}$ & $\begin{array}{ll}\text { - } & \text { Informasi yang } \\
\text { dihasilkan tidak akurat } \\
\text { - } \quad \text { Sistem berjalan yang ada } \\
\text { bisa mengalami } \\
\text { kesalahan }\end{array}$ \\
\hline Tempat & $\begin{array}{l}\text { - Ruang Penyimpanan } \\
\text { terbatas }\end{array}$ & $\begin{array}{ll}\text { - } & \text { Dokumen dan berkas yang ada } \\
\text { terlalu banyak dan menumpuk } \\
\text { - } \\
\text { Memungkinkan dokumen mudah } \\
\text { hilang dan rusak }\end{array}$ & - $\quad$ Sulit dalam mencari data \\
\hline Proses & $\begin{array}{l}\text { - } \\
\text { lapulit dalam membuat } \\
\text { penjualan }\end{array}$ & $\begin{array}{ll}\text { - } & \text { Keluar masuk barang tidak di } \\
\text { update dengan benar } \\
\text { - } \\
\text { Dalam membuat laporan terlalu } \\
\text { banyak merekap ulang dengan } \\
\text { pengecekan dokumen pendukung }\end{array}$ & 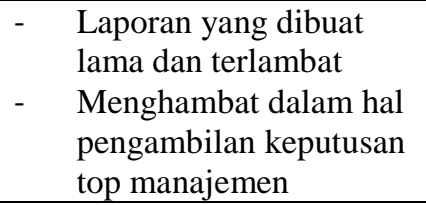 \\
\hline
\end{tabular}

Sumber : (Laraswati \& Ariani, 2019)

\section{Analisa kebutuhan}

Pada analisa kebutuhan terdapat beberapa tahapan, yaitu :

\section{a. Tahapan analisis}

Dalam sistem ini terdapat dua user yang saling berhubungan dalam sistem tersebut : admin dan bagian penjualan.
1) Bagian Admin

a) Admin dapat melakukan login b) Admin dapat mengelola data barang

c) Admin dapat mengelola data customer

d) Admin dapat mengelola data user

e) Admin dapat mengelola data penjualan

f) Admin dapat mengelola data pengiriman

g) Admin dapat mengelola data pembayaran

h) Admin dapat melihat laporan penjualan

i) Admin dapat melakukan backup data

2) Bagian Penjualan

a) Bagian penjualan dapat melakukan login 
b) Bagian penjualan dapat mengelola data penjualan

c) Bagian penjualan dapat mengelola data pengiriman

d) Bagian penjualan dapat mengelola data pembayaran

e) Bagian penjualan dapat melakukan ganti password

\section{b. Usecase Diagram}

Usecase diagram dirancang sesuai dengan kebutuhan sistem yang dibuat. Yaitu untuk admin dan bagian penjualan. Diagram ini untuk menampilkan rancangan sistem dilihat dari fungsional sistem, yang dirancang.



Sumber : (Laraswati \& Ariani, 2019)

Gambar 2. Diagram Usecase

Tabel 2. Deskripsi Usecase

\begin{tabular}{|l|l|l|}
\hline No. & Use Case & \multicolumn{1}{|c|}{ Deskripsi } \\
\hline 1 & Data Barang & $\begin{array}{l}\text { Pada proses ini User (admin) } \\
\text { dapat mengelola data barang. } \\
\text { Seperti menambah, edit dan } \\
\text { hapus. }\end{array}$ \\
\hline 2 & $\begin{array}{l}\text { Data } \\
\text { Customer }\end{array}$ & $\begin{array}{l}\text { Pada proses ini User (admin) } \\
\text { dapat mengelola data } \\
\text { customer. }\end{array}$ \\
\hline 3 & Data User & $\begin{array}{l}\text { Pada proses ini User (admin) } \\
\text { dapat mengelola data user. } \\
\text { Siapa saja yang dapat } \\
\text { mengakses sistem ini }\end{array}$ \\
\hline 4 & Data & Pada tahapan ini user dapat \\
\hline
\end{tabular}

\begin{tabular}{|l|l|l|}
\hline No. & Use Case & \multicolumn{1}{|c|}{ Deskripsi } \\
\hline 5 & Penjualan & $\begin{array}{l}\text { menginput penjualan yang } \\
\text { terjadi. }\end{array}$ \\
\hline 6 & $\begin{array}{l}\text { Data } \\
\text { pengiriman } \\
\text { pembayaran }\end{array}$ & $\begin{array}{l}\text { jaka penjualan sudah di input } \\
\text { dan disiapkan. Maka diinput } \\
\text { data pengiriman }\end{array}$ \\
\hline 7 & $\begin{array}{l}\text { Pada tahap ini user (admin) } \\
\text { pembayaran yang yang telah } \\
\text { diterima dari customer. }\end{array}$ \\
\hline 8 & Backup data & $\begin{array}{l}\text { Pada tahap ini laporan } \\
\text { penjualan dapat di cetak. }\end{array}$ \\
\hline $\begin{array}{l}\text { Backup data dapat dilakukan } \\
\text { untuk menjaga keamanan } \\
\text { data. }\end{array}$ \\
\hline
\end{tabular}

Sumber : (Laraswati \& Ariani, 2019)

\section{c. Activity Diagram}

Activity diagram menggambarkan berbagai alir aktivitas dalam sistem yang sedang dirancang.

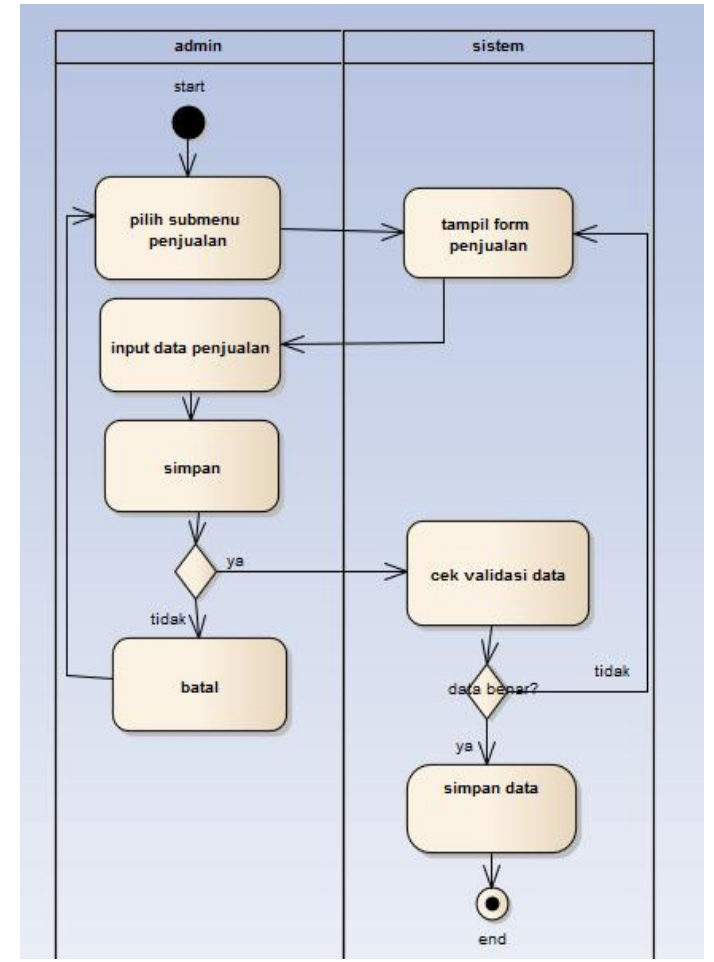

Sumber : (Laraswati \& Ariani, 2019)

Gambar 3. Activity Diagram penjualan

\section{Perancangan (Design)}

Pada tahap desain adalah tahap yang menjelaskan tetang desain database, desain software arhitecture dan desain interface dari sistem yang sedang dibuat.

a. Database

Database yang dibuat dalam sistem ini adalah :

1) ERD (Entity Relationship Diagram)

Pada ERD ini terdapat delapan entity yang saling berhubungan. 


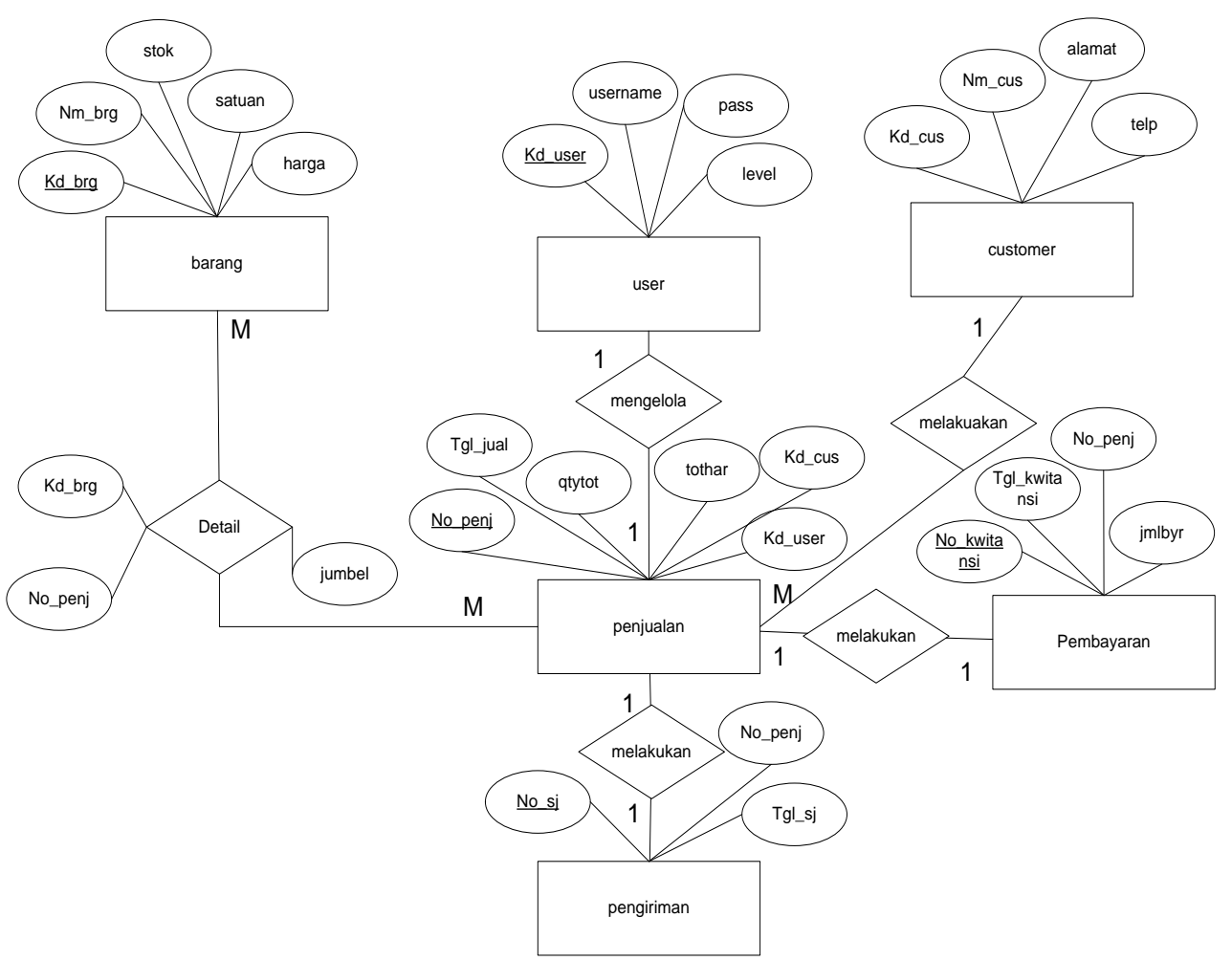

Sumber : (Laraswati \& Ariani, 2019)

Gambar 4. Entity Relationship Diagram

2) Logical Record Structure (LRS)

Rancangan logical record structure digambarkan sebangai berikut. Dimana gambar ini menunjukan alur logika dari suatu record pada program yang dibuat.

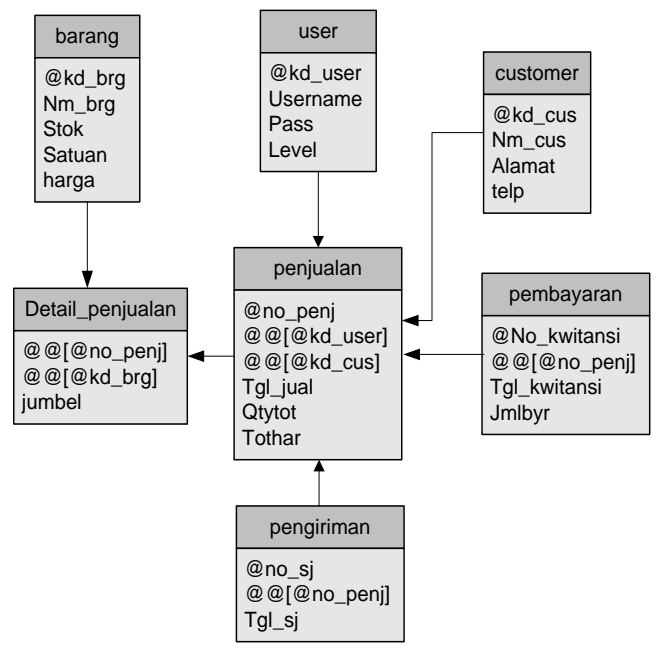

Sumber : (Laraswati \& Ariani, 2019)

Gambar 5. Logical Record Structure (LRS)

b. Software Architecture

1) Deployment Diagram

Deployment diagram digunakan untuk menggambarkan atau memvisualisasikan secara umum proses yang terjadi pada suatu sistem atau software.

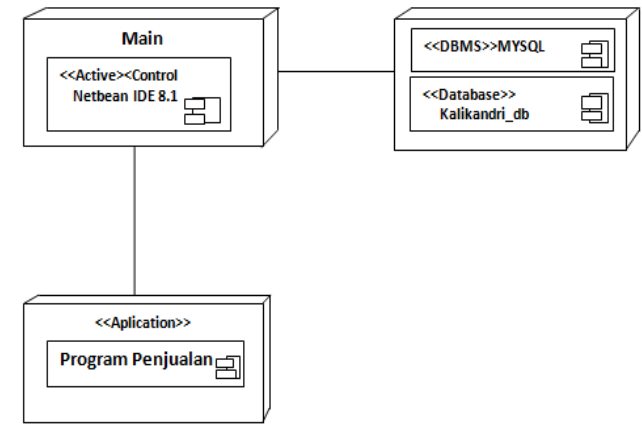

Sumber : (Laraswati \& Ariani, 2019)

Gambar 6. Deployment Diagram 


\section{2) Sequence Diagram}

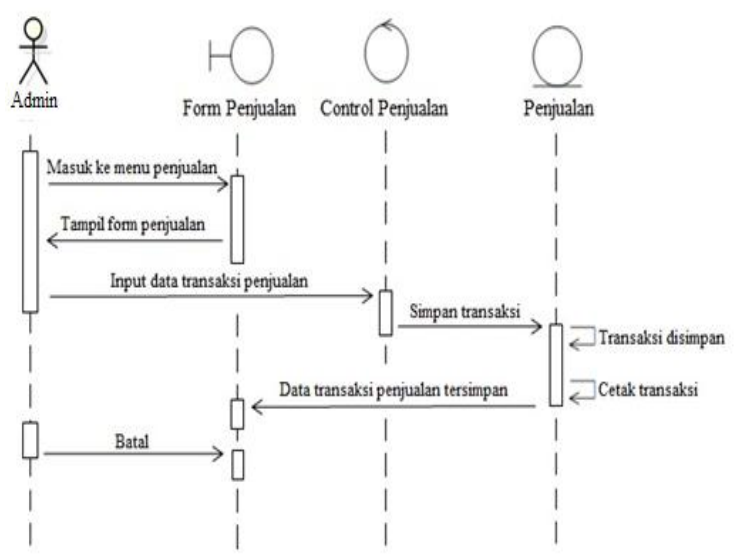

Sumber : (Laraswati \& Ariani, 2019)

Gambar 7. Sequence Diagram penjualan

c. Rancangan user inteface

Berikut beberapa tampilan dari rancangan sistem penjualan peralatan kesehatan yang dibuat :

1) Rancangan form data barang

Rancangan ini digunakan oleh admin untuk mengelola data barang.

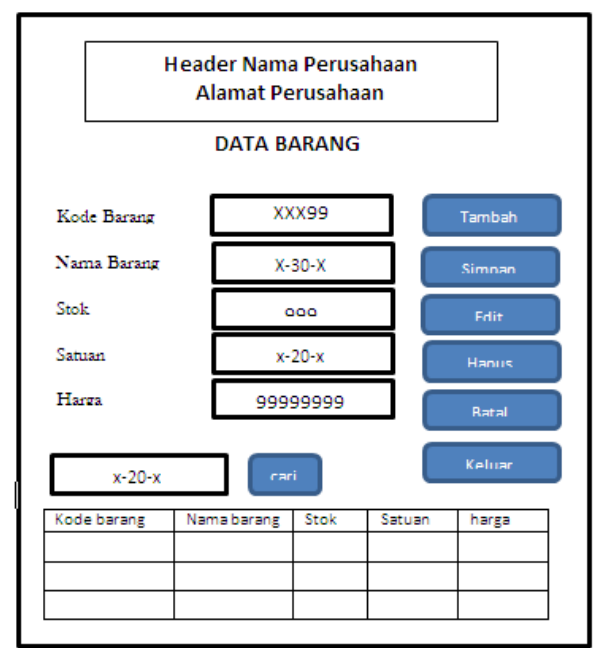

Sumber : (Laraswati \& Ariani, 2019)

Gambar 8. Form Data barang

2) Rancangan form penjualan

Form ini dirancang untuk menginput transaksi penjualan peralatan kesehaan.

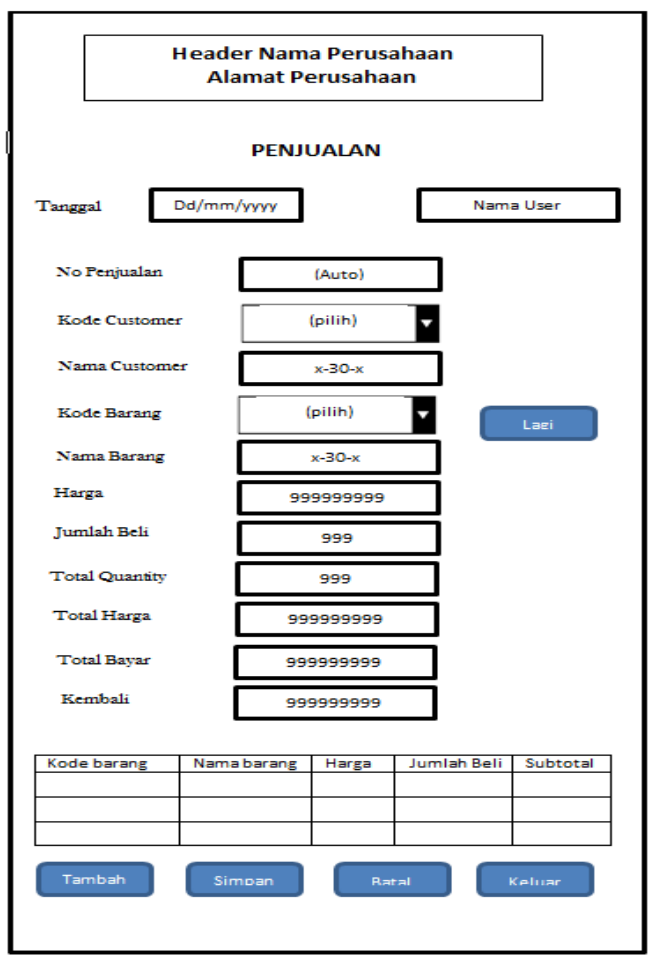

Sumber : (Laraswati \& Ariani, 2019)

Gambar 9. Form penjualan

\section{Pengujian}

Pengujian fokus pada perangkat lunak secara dari segi lojik dan fungsional dan memastikan bahwa semua bagian sudah diuji. Hal ini dilakukan untuk meminimalisir kesalahan (error) dan memastikan keluaran yang dihasilkan sesuai yang diinginkan (Rizal, 2018).

Untuk tahap pengujian atau testing, penulis menggunakan pengujian dengan metode blackbox, dimana pengujiannya dilakukan pada tampilan program apakah program dapat berjalan sesuai yang diinginkan.

Tabel 3. Pengujian blackbox Form Data Barang

\begin{tabular}{|l|l|l|l|}
\hline $\begin{array}{l}\text { Kelas } \\
\text { Uji }\end{array}$ & $\begin{array}{l}\text { Skenario } \\
\text { Uji }\end{array}$ & $\begin{array}{l}\text { Hasil Yang } \\
\text { diharapkan }\end{array}$ & $\begin{array}{l}\text { Kesimpu } \\
\text { lan }\end{array}$ \\
\hline $\begin{array}{l}\text { Input } \\
\text { Kode } \\
\text { Barang }\end{array}$ & $\begin{array}{l}\text { Tiga digit } \\
\text { pertama } \\
\text { karakter dan } \\
\text { dua digit } \\
\text { terakhir } \\
\text { numerik }\end{array}$ & $\begin{array}{l}\text { Bila Kode } \\
\text { barang sudah } \\
\text { ada, tampil } \\
\text { data barang. }\end{array}$ & Sesuai \\
\hline $\begin{array}{l}\text { Input } \\
\text { stok }\end{array}$ & $\begin{array}{l}\text { Menggunak } \\
\text { an numerik }\end{array}$ & $\begin{array}{l}\text { Tidak bisa } \\
\text { terinput selain } \\
\text { menggunakan } \\
\text { angka / } \\
\text { numerik }\end{array}$ & Sesuai \\
\hline $\begin{array}{l}\text { Cari } \\
\text { nama } \\
\text { barang }\end{array}$ & $\begin{array}{l}\text { Input nama } \\
\text { barang yang } \\
\text { dicari }\end{array}$ & $\begin{array}{l}\text { Tampil data } \\
\text { barang yang } \\
\text { dicari }\end{array}$ & Sesuai \\
\hline
\end{tabular}




\begin{tabular}{|l|l|l|l|}
\hline $\begin{array}{l}\text { Form } \\
\text { data } \\
\text { barang }\end{array}$ & $\begin{array}{l}\text { menambah, } \\
\text { mengedit, } \\
\text { menyimpan } \\
\text { dan } \\
\text { menghapus }\end{array}$ & $\begin{array}{l}\text { Masuk ke form } \\
\text { data barang. } \\
\text { Dapat } \\
\text { menambah, } \\
\text { menyimpan, } \\
\text { mengedit dan } \\
\text { menghapus } \\
\text { data barang }\end{array}$ & \\
& & & \\
\hline
\end{tabular}

Tabel 4. Pengujian blackbox Form Penjualan

\begin{tabular}{|c|c|c|c|}
\hline Kelas Uji & $\begin{array}{l}\text { Skenario } \\
\text { Uji }\end{array}$ & $\begin{array}{l}\text { Hasil Yang } \\
\text { diharapkan }\end{array}$ & $\begin{array}{l}\text { Kesimpula } \\
\mathrm{n}\end{array}$ \\
\hline $\begin{array}{l}\text { Tambah } \\
\text { transaksi }\end{array}$ & $\begin{array}{l}\text { Klik } \\
\text { tombol } \\
\text { tambah }\end{array}$ & $\begin{array}{l}\text { No } \\
\text { penjualan } \\
\text { tampil } \\
\text { otomatis }\end{array}$ & Sesuai \\
\hline $\begin{array}{l}\text { Pilih Kode } \\
\text { customer }\end{array}$ & $\begin{array}{l}\text { Pilih } \\
\text { kode } \\
\text { customer }\end{array}$ & $\begin{array}{l}\text { Tampil } \\
\text { nama } \\
\text { customer }\end{array}$ & Sesuai \\
\hline $\begin{array}{l}\text { Pilih Kode } \\
\text { barang }\end{array}$ & $\begin{array}{l}\text { Pilih } \\
\text { Kode } \\
\text { barang }\end{array}$ & $\begin{array}{l}\text { Tampil } \\
\text { nama } \\
\text { barang dan } \\
\text { harga }\end{array}$ & Sesuai \\
\hline $\begin{array}{l}\text { Input } \\
\text { jumlah } \\
\text { beli }\end{array}$ & $\begin{array}{l}\text { Menggun } \\
\text { akan } \\
\text { numerik }\end{array}$ & $\begin{array}{l}\text { Tidak bisa } \\
\text { terinput } \\
\text { selain } \\
\text { menggunak } \\
\text { an angka / } \\
\text { numerik }\end{array}$ & Sesuai \\
\hline $\begin{array}{l}\text { Tombol } \\
\text { Lagi }\end{array}$ & $\begin{array}{l}\text { Klik } \\
\text { tolmbol } \\
\text { lagi }\end{array}$ & $\begin{array}{l}\text { Data } \\
\text { penjualan } \\
\text { akan masuk } \\
\text { ke dalam } \\
\text { tabel, total } \\
\text { quantity dan } \\
\text { total harga } \\
\text { muncul. } \\
\text { Pilih lagi } \\
\text { untuk } \\
\text { menambah } \\
\text { barang } \\
\end{array}$ & sesuai \\
\hline $\begin{array}{l}\text { Input } \\
\text { Total } \\
\text { Bayar }\end{array}$ & $\begin{array}{l}\text { Input } \\
\text { bayar } \\
\text { menggun } \\
\text { akan } \\
\text { numerik/ } \\
\text { angka }\end{array}$ & $\begin{array}{l}\text { Tidak bisa } \\
\text { terinput } \\
\text { selain } \\
\text { menggunak } \\
\text { an angka / } \\
\text { numerik dan } \\
\text { kembali } \\
\text { tampil }\end{array}$ & Sesuai \\
\hline $\begin{array}{l}\text { Form } \\
\text { penjualan }\end{array}$ & $\begin{array}{l}\text { Menamb } \\
\text { ah dan } \\
\text { menyimp } \\
\text { an }\end{array}$ & $\begin{array}{l}\text { Masuk ke } \\
\text { form } \\
\text { penjualan. } \\
\text { Dapat } \\
\text { menambah, } \\
\text { menyimpan, } \\
\text { data } \\
\text { penjualan }\end{array}$ & Sesuai \\
\hline
\end{tabular}

\section{Pemeliharaan}

Proses ini dilakukan setelah sistem informasi penjualan PT. Kalikandri Banyu Bening tersebut telah digunakan oleh user. Perubahan atau pemeliharaan akan dilakukan jika terdapat kesalahan, oleh karena itu program tersebut harus disesuaikan lagi untuk menampung perubahan kebutuhan yang diinginkan pengguna, sebagai bentuk pengembangan dan pemeliharaan sistem informasi penjualan PT. Kalikandri Banyu Bening.

\section{KESIMPULAN}

Berdasarkan observasi serta analisa sistem penjualan yang dilakukan pada PT. Kaliandri Banyu Bening, maka peneliti dapat menyimpulkan dengan dibangunnya Sistem Informasi Penjualan Peralatan Kesehatan sangat membantu dalam proses pengolahan data barang khususnya stok barang, pengolahan data customer, pengolahan data transaksi penjualan sampai dengan pembuatan bukti transaksi dan laporan setiap bulannya. Dimana selama ini sistem berjalan yang ada masih bersifat konvensional dengan proses pengerjaanya manual yang menyebabkan beberapa kendala atau masalah yang bisa dilihat pada diagram fishbone, seperti dokumen dan berkas menumpuk dan tidak tertata dengan baik, maka memungkinkan data mudah hilang ataupun rusak serta kesulitan dalam mencari data, tidak adanya hak ases user sehingga data mudah dimanipulasi, pengolahan transaksi penjualan sampai dengan pembuatan laporan memakan waktu yang lama, sehingga informasi yang dihasilkan cenderung terlambat dan tidak akurat.

Dengan pembangunan sistem automatisasi penjualan penjualan peralatan kesehatan maka capaian akan perusahaan yang berkembang menjadi lebih baik lagi dalam kecepatan melayani customer, memudahkan admin dalam mengolah data transaksi penjualan sampai dengan pembuatan laporan. Bagi top manajemen dengan informasi yang valid dan cepat maka akan memudahkan dalam pengambilan keputusan demi kemajuan perusahaan.

\section{REFERENSI}

Basry, A., \& Sari, E. M. (2018). Penggunaan Teknologi Informasi dan Komunikasi (TIK) pada Usaha Mikro, Kecil dan Menengah (UMKM). IKRA-ITH INFORMATIKA : Jurnal Komputer Dan Informatika, 2(3), 53-60. Retrieved from http://journals.upiyai.ac.id/index.php/ikraithinformatika/article/view/266

Christian, A., \& Ariani, F. (2018). Rancang Bangun Sistem Informasi Peminjaman Perangkat Demo Video Conference Berbasis Web Dengan Metode Waterfall. Jurnal Pilar Nusa Mandiri, 14(1), 131-136.

Laraswati, D., \& Ariani, F. (2019). Laporan 
Penelitian Sistem Informasi Penjualan Peralatan Kesehatan.

Laraswati, D., \& Marlina. (2019). Rancang Bangun

Sistem Informasi pelayanan Paket Pernikahan Pada Mindo Wedding Organizer. IJSEIndonesian Journal on Software Engineering, 5(1), 1-8. Retrieved from https://ejournal.bsi.ac.id/ejurnal/index.php/ijse /article/view/6177

Rizal, K. (2018). Rancang Bangun Sistem Informasi Penjualan Obat Berbasis Dekstop dengan Model Waterfall. Jurnal Swabumi, 6(2), 117-
122.

Susanto, S., \& Irawan, H. (2018). Analisa Dan Desain Sistem Informasi Administrasi Pengadaan Alat Tulis Kantor Menggunakan Unified Modelling Language Studi Kasus: Amik Pakarti Luhur Kota Tangerang. J u r n a l I D E A L I S, 1, 410-415.

Yuni, I. M. N., \& Muryani, S. (2018). Rancang Bangun Sistem Informasi Penjualan Perabotan Pada CV . Evamas. Jurnal Paradigma, XX(2), 1-8. https://doi.org/10.31294/p.v20i2.3838 